\title{
Immune system and prognosis in colorectal cancer: a detailed immunohistochemical analysis
}

\author{
Anand G Menon ${ }^{1,2}$, Connie M Janssen - van Rhijn ${ }^{1}$, Hans Morreau ${ }^{2}$, Hein Putter ${ }^{3}$, \\ Rob AEM Tollenaar ${ }^{1}$, Cornelis JHvan de Velde ${ }^{1}$, Gert Jan Fleuren ${ }^{2}$ and Peter JK Kuppen ${ }^{1}$ \\ ${ }^{1}$ Department of Surgery, University Medical Center, Leiden, The Netherlands; ${ }^{2}$ Department of Pathology, \\ University Medical Center, Leiden, The Netherlands and ${ }^{3}$ Department of Medical Statistics of the Leiden \\ University Medical Center, Leiden, The Netherlands
}

\begin{abstract}
The efficacy of tumor cell-immune cell interactions depends on a number of factors, for example, the expression of HLA-I on tumor cells, the type of immune cell, the accessibility of tumor cells for immune cells and the expression of immunogenic epitopes. We assessed infiltration of $\mathrm{CD}_{4}^{+}, \mathrm{CDB}^{+}, \mathrm{CD}^{+} 6^{+}$and $\mathrm{CD} 57^{+}$cells in the tumor epithelium, tumor stroma and advancing tumor margin of 93 colorectal carcinomas and correlated this to clinicopathological parameters, the expression of HLA-A and HLA-B/C on tumor cells, the presence of a basal membrane (BM)-like structure surrounding tumor nodules and the presence of microsatellite instability/ mutator phenotype (absent MLH-1 expression). The median intraepithelial CD4 ${ }^{+}, \mathrm{CD8}^{+}, \mathrm{CD}^{+}{ }^{+}$and $\mathrm{CD}^{+} 7^{+}$cell infiltrations were $3,23,0$ and 0 cells $/ \mathrm{mm}^{2}$ tumor, respectively. HLA-A/BC expression by tumor cells was normal in $\mathbf{2 8} / \mathbf{4 3} \%$, heterogeneous in $59 / 48 \%$ and absent in $13 / 9 \%$ of the cases. A BM-like structure surrounding the tumor nodules was absent, present and thick in 47,38 and $15 \%$ of the cases. Six cases lost MLH1 expression. There was a positive correlation between leukocyte infiltration in the three compartments for $\mathrm{CD4}^{+}, \mathrm{CDB}^{+}$, $\mathrm{CD}^{+}{ }^{+}$(partly) and $\mathrm{CD}^{+} 7^{+}$(all $\boldsymbol{P}<0.05$ ) cell infiltration. Intraepithelial $\mathrm{CD8}{ }^{+}$cell infiltration inversely correlated with HLA-A $(P=0.04)$ and HLA-B/C expression $(P=0.04)$. Intraepithelial $\mathrm{CD}^{+} 7^{+}$cell infiltration inversely correlated with HLA-B/C expression $(P=0.04)$. Moreover, intraepithelial infiltration of $\mathrm{CDB}^{+}$and $\mathrm{CD}^{+} 7^{+}$cells was inversely correlated to the presence of a BM-like structure $(P=0.003$ and 0.04 , respectively). Uni- and multivariate analyses showed that a lower tumor stage $(P=0.004)$ and marked infiltration of CD8 ${ }^{+}(P=0.04)$ and $\mathrm{CD}^{+} 7^{+}$cells $(P=0.05)$ at the advancing tumor margin were independent prognostic factors for a longer diseasefree survival. Loss of MLH1 expression was correlated with a significantly higher intraepithelial CD8 $^{+}$and $\mathrm{CD}^{2} 7^{+}$cell infiltration. We conclude that infiltration of $\mathrm{CD8}^{+}$and $\mathrm{CD}^{+} 7^{+}$cells are important prognostic factors in colorectal cancer. However, their interaction with tumor cells is inversely correlated to the presence of HLA-I on tumor cells and a thick BM-like structure around tumor islets. Our data indicate that NK cells might play an important role in the immune surveillance in colorectal cancer patients.
\end{abstract}

Laboratory Investigation (2004) 84, 493-501, advance online publication, 16 February 2004; doi:10.1038/labinvest.3700055

Keywords: colorectal cancer; prognosis; tumor-infiltrating leukocytes; natural killer cells; microsatellite instability; extracellular matrix protein

Many immunohistochemical studies on tumor specimens suggest that the immune system can play a role in containing tumor cells in colorectal cancer. ${ }^{1-4}$ However, these studies have not taken into account some important recent findings.

Firstly, many immunohistochemical studies quantified the presence of immune cells on hematoxylineosin (HE)-stained tumor sections, but this method

Correspondence: Dr PJK Kuppen, Department of Surgery, K6-R, Leiden University Medical Center, PO Box 9600, 2300 RC Leiden, The Netherlands. E-mail: P.J.K.Kuppen@lumc.nl

Received 31 December 2002; revised 8 December 2003; accepted 9 December 2003; published online 16 February 2004 has a number of drawbacks. For instance, it has been shown that estimating the amount of tumor-infiltrating immune cells on HE sections is sensitive to interobserver variability ${ }^{5}$ and underestimates the true number of leukocytes in a tumor. ${ }^{6}$ In addition, it is difficult to characterize the tumor-infiltrating immune cells morphologically, that is, whether a particular cell is a T-helper $\left(\mathrm{T}_{\mathrm{H}}, \mathrm{CD}^{+}\right)$, cytotoxic $\mathrm{T}$ lymphocyte $\left(\mathrm{CTL}, \mathrm{CD}^{+}\right)$or natural killer (NK) cell $\left(\mathrm{CD}^{-} / \mathrm{CD}^{2} 6^{+}\right.$, and subsets of $\mathrm{CD}^{+}$or $\mathrm{CD} 57^{+}$). Another important feature that is difficult to appreciate on HE-stainings is whether immune cells are in direct contact with tumor cells, that is, located in the tumor-epithelium compartment, or located in 
the stroma. Naito et $a l^{7}$ recently showed that CD8 ${ }^{+}$ lymphocytes that were located in the tumor stroma or tumor margin did not affect prognosis, whereas only those $\mathrm{CD}^{+}$lymphocytes located in the tumor epithelium affected the prognosis positively. ${ }^{7}$ Moreover, the presence of a substantial thickening of the extracellular matrix (ECM), a basal-membrane(BM)-like structure, around tumor cell nests seems to prevent direct contact between leukocytes and tumor cells. ${ }^{8,9}$ Recently, we found that the presence of this BM-like structure indeed correlated with significantly less intraepithelial leukocytes and a worse prognosis. ${ }^{10}$ This suggests that, in addition to the location of immune cells, the presence of a BM-like structure should also be taken into account.

Another important tumor feature that has important consequences for the presence of tumor-infiltrating leukocytes is the expression of immunogenic epitopes on tumor cells. Defects in mismatch repair genes, which are the hallmark of the hereditary nonpolyposis colorectal cancer (HNPCC) syndrome and can also be found in $15-20 \%$ of sporadic colorectal cancers, result in the introduction of mutations at repetitive nucleotides in the genome (microsatellites (MS), mutator phenotype) that are potentially immunogenic. Based on the extent of mutations, tumors can be categorized as MS-stable, or MS instability (MSI)-low (characterized by relatively few mutations at nucleotide repeats) or MSIhigh (characterized by many mutations at nucleotide repeats) on the basis of defined criteria. ${ }^{11}$ These latter tumors form an interesting category, because they are characterized by a marked inflammatory reaction and a good prognosis. Studies by Dolcetti et $a{ }^{12}$ and Guidoboni et al. ${ }^{13}$ showed that the inflammatory response consisted mainly of activated $\mathrm{CD}^{+}$and $\mathrm{CD}^{+}{ }^{+}$cells, which implies the presence of cytotoxic T lymphocytes (CTL) and/or CD8 ${ }^{+}$NK cells. ${ }^{14,15}$ It is important in this respect, to take into account the fact that MSI-high tumors frequently show loss of expression of the human leukocyte anigen class I (HLA-I). ${ }^{16}$ Loss of HLA-I would allow these tumor cells to escape CTLmediated lysis; however, they may become a target for NK cells. The presence and prognostic importance of immune cell subsets in colorectal cancer is not very well known. Therefore, in the present study, we evaluated the prognostic impact of infiltration of $\mathrm{CD}^{+}{ }^{+}, \mathrm{CD}^{+}, \mathrm{CD}^{+} 6^{+}$and $\mathrm{CD} 57^{+}$cells in 93 primary colorectal cancers, taking into account beforementioned important factors, that is, HLA-I expression on tumor cells, direct contact with tumor cells and the presence of the mutator phenotype.

\section{Materials and methods}

\section{Patients}

An unselected group of 93 curatively operated, colorectal cancer patients was analyzed. The med- ian age of the patients was 69 years (range: 26-85 years; s.d.: 12 years). Tumors were evaluated for tumor location, tumor stage, differentiation grade and mucinous characteristics.

\section{Immunohistochemistry}

Tissue sections ( $5 \mu \mathrm{m})$ were prepared on aminopropylethoxysilane (APES)-coated slides, and dried overnight at $37^{\circ} \mathrm{C}$. Tissue sections were deparaffinized in xylol for $15 \mathrm{~min}$ and subsequently rinsed in ethanol. Endogenous peroxidase was blocked for $20 \mathrm{~min}$ in $0.3 \%$ hydrogen-peroxide methanol, and subsequently, the sections were rehydrated. Antigen retrieval for the CD markers consisted of boiling the tissue sections in $1 \mathrm{mM}$ EDTA solution ( $\mathrm{pH}$ 8.0) for $10 \mathrm{~min}$ and allowing them to cool down in it for $2 \mathrm{~h}$. Subsequently, the sections were washed in phosphate buffered saline (PBS) for $10 \mathrm{~min}$ and incubated overnight at room temperature with one of the following CD markers: anti-CD4 (1:50, clone F6, Novocastra), anti-CD8 (1:400, clone 4B11, Novocastra), anti-CD56 (1:800, clone 123C3, Zymed) and anti-CD57 (1:500, HNK-1 hybridoma, ATCC). After overnight incubation with the $\mathrm{CD}$ marker, the sections were washed in PBS for $15 \mathrm{~min}$ and incubated with mouse Envision labelled with Horse Raddish Peroxidase (m-Envision ${ }^{\text {HRP }}$, Code No. K4001) for $30 \mathrm{~min}$. The sections were then washed in PBS for $15 \mathrm{~min}$, rinsed in $0.05 \mathrm{M}$ Tris-HCl buffer (pH 7.6) for $5 \mathrm{~min}$ and developed in 3,3-di-aminobenzidine tetrahydrochloride (DAB) with $0.002 \%$ hydrogen peroxide for $10 \mathrm{~min}$, which results in a brown signal. The reaction was blocked in demiwater. Subsequently, the sections were incubated at $37^{\circ} \mathrm{C}$ in a $0.01 \%$ trypsin (Sigma, T7409) in $0.1 \mathrm{CaCl}_{2}$ for $10 \mathrm{~min}$ after which the trypsin reaction was stopped in demi-water. After washing in PBS for $5 \mathrm{~min}$, the tissue sections were incubated overnight at room temperature with a rabbit polyclonal antibody against human laminin (1:50, Sigma) diluted in PBS/1\% BSA. On the third day, the sections were washed in PBS for $15 \mathrm{~min}$, incubated for $30 \mathrm{~min}$ with Swine-anti-Rabbit labelled with biotin SWAR $^{\text {biotin }}$, 1:100, DAKO, Glostrup, Denmark) and washed with PBS for $15 \mathrm{~min}$. Subsequently, the sections were incubated for $30 \mathrm{~min}$ with streptavidin-biotin complex (1:100, DAKO) labelled with alkaline phosphatase. After washing the sections in PBS for $15 \mathrm{~min}$, and rinsing for $5 \mathrm{~min}$ in an alkaline phosphatase buffer $(100 \mathrm{mM}$ TRIS, $100 \mathrm{mM} \mathrm{NaCl}$ and $5 \mathrm{mM}$ $\mathrm{MgCl}_{2} \cdot 6 \mathrm{H}_{2} \mathrm{O} ; \mathrm{pH}$ 9.5), the sections were developed in an NBT/BCIP solution (10 ml AP buffer with $66 \mu$ l NBT (Promega S380C, $50 \mathrm{mg} / \mathrm{ml}$ in $70 \%$ dimethylformamid), $33 \mu \mathrm{l}$ BCIP (Promega S381C, $50 \mathrm{mg} / \mathrm{ml}$ in $100 \%$ dimethylformamid and $100 \mu \mathrm{l}$ levamisole (Sigma, L9756) for $10 \mathrm{~min}$. The reaction was blocked in demi-water and the slides were dried overnight at room temperature. The sections were mounted in Kaizer's glycerin, a water-based mounting medium. 
A negative control was included for each tumor sample by using PBS/BSA instead of the CD and laminin antibody in the overnight incubations.

\section{Microscopic Evaluation of Tumor Sections}

One tissue section that was representative of the tumor was chosen for analysis. Microscopic analysis was carried out without knowledge of the clinical outcome of the patients. HLA-A and HLA-B/C expression were evaluated separately. The expression of HLA was categorized as normal when all tumor cells showed membranous expression, heterogeneous when tumor cells without expression coexisted with HLA-expressing tumor cells or absent when none of the tumor cells expressed HLA and the internal control (stroma, leukocytes, endothelium) was positive. ${ }^{17}$ As previously described, an ocular grid, with a total surface area of $38 \mathrm{~mm}^{2}$, was used at a $\times 200$ magnification to count all leukocytes that were located intraepithelially in 25 different tumor fields of the tissue section. ${ }^{10}$ Laminin was used to distinguish between intraepithelially, that is, leukocytes in the direct vicinity of tumor cells, and intrastromally located leukocytes (see Figure 1). This careful analysis made it possible to calculate the number of leukocytes per tumor area (leukocytes $/ \mathrm{mm}^{2}$ tumor epithelium). The average leukocyte infiltration of 25 fields per tumor section was calculated and defined as the intraepithelial leukocyte infiltration. Leukocytes in the tumor stroma and tumor margin were estimated semiquantitatively in the same tissue section as previously described. ${ }^{7}$ The advancing tumor margin was defined as the transition zone between the periphery of the tumor and normal colonic tissue. In addition, tumor-'infiltrating' leukocytes were assessed semi-

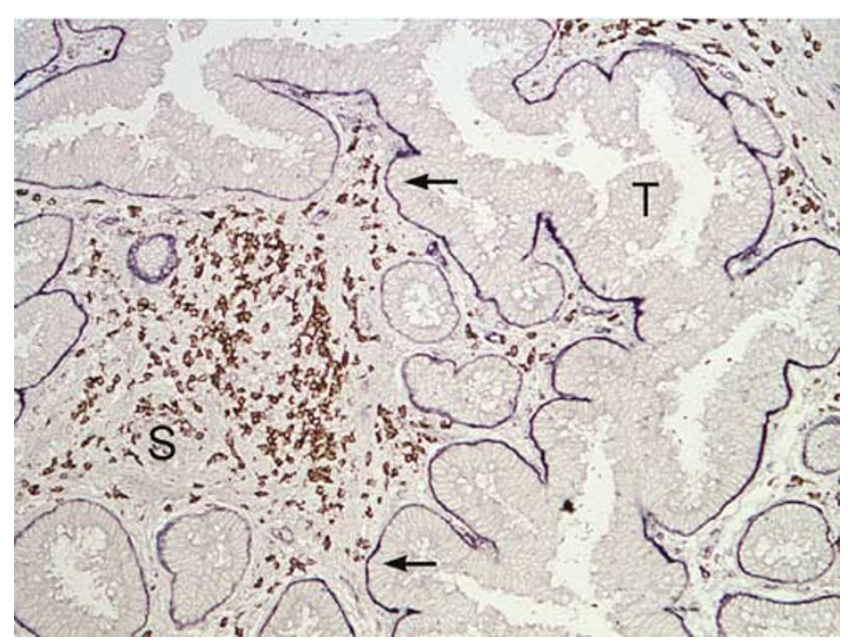

Figure 1 A colorectal cancer specimen was stained for CD8 and laminin. $\mathrm{CD}^{+}$cells (red) are located in the tumor stroma (S) and not in the tumor epithelium (T). A thick laminin wall (arrow) separates the tumor-epithelium- compartment from the tumorstroma compartment. quantitatively into 'none-poor' or 'moderate marked' leukocyte infiltration using routinely HEstained tumor sections and has been shown to have prognostic value. ${ }^{4}$ The presence of a BM-like structure surrounding the tumor epithelium was assessed in each slide based on the immunohistochemical staining with antilaminin and scored as absent, normal or thick in comparison to the BM in normal colon epithelial tissue that was present in the same tissue section. MLH1 expression was categorized as absent (suggesting MSI) if the majority of tumor cells lacked nuclear MLH1 expression. These cases were termed $\mathrm{MSI}^{+}$.

\section{Statistical Analysis}

As previously described, a group with high and low intraepithelial leukocyte infiltration was distinguished based on the 75th percentile of the average leukocyte-infiltration scores of all patients. ${ }^{18}$ All statistical analyses were carried out using the SPSS software package (SPSS Inc., Chicago, IL, USA). The $\chi^{2}$-test (exact test in case of $<5$ cases was used to evaluate differences between various clinicopathological parameters and leukocyte infiltration). In case of cells with less than five expected subjects, Fisher's exact test was used. The Kaplan-Meier method was used to calculate the disease-free survival (DFS) analyses and the log-rank test was used for comparison of the survival curves. Groups with less than five subjects were grouped with the appropriate, adjacent groups for statistical analyses. Cox regression was used for multivariate analysis.

\section{Results}

\section{Patients and Tumors}

In total, 56 men (60\%) and 37 women (40\%) underwent curative resections confirmed on histopathological evaluation. Patient- and tumor features are shown in Table 1. Tumors were staged as stage II (Dukes B) in 44 patients (47\%) and stage III (Dukes C) in 49 patients (53\%). Tumor differentiation could not be assessed in three cases $(3 \%)$. The median follow-up was 6.1 years (range: 0.1-18.6 years, standard deviation (s.d.): 5.0 years).

\section{Infiltration of $\mathrm{CD4}^{+}, \mathrm{CD8}^{+}, \mathrm{CD56}^{+}$and $\mathrm{CD57}^{+}$Cells in the Tumor epithelium and Tumor-stroma Compartment and Expression of HLA-A and HLA-B/C}

The 75th percentile of intraepithelial leukocyte infiltration was chosen as a cutoff point to distinguish between a group with high and low leukocyte infiltration (Table 1). The 75th percentile was 10 cells $/ \mathrm{mm}^{2}$ tumor for CD4, 65 cells $/ \mathrm{mm}^{2}$ tumor for CD8, 5 cells $/ \mathrm{mm}^{2}$ tumor for CD56 and 2 cells $/ \mathrm{mm}^{2}$ tumor for CD57. Infiltration in the tumor stroma and tumor margin was assessed semiquantitatively 
(Table 1). An example of a tumor specimen that was double-stained with anti-CD8 and -laminin is shown in Figure 1. The degree of inflammatory reaction was also assessed on HE-stained tumor sections. Leukocyte infiltration (Table 1) was assessed as poor $(n=35,38 \%)$, moderate $(n=43,46 \%)$ or marked $(n=15,16 \%)$.

Table 1 Patient and tumor characteristics and impact on DFS

\begin{tabular}{|c|c|c|c|c|}
\hline Parameter & & n $(\%)$ & $\begin{array}{c}\text { Mean } \\
\text { DFS } \\
\text { (months) }\end{array}$ & $P$-value \\
\hline \multirow[t]{2}{*}{ Gender } & Male & $56(60)$ & 11.8 & 0.19 \\
\hline & Female & $37(40)$ & 12.8 & \\
\hline \multirow[t]{2}{*}{ Age (years) } & $<50$ & $12(13)$ & 11.6 & 0.55 \\
\hline & $>50$ & $81(87)$ & 12.8 & \\
\hline \multirow{2}{*}{ Location } & Colon & $58(62)$ & 12.9 & 0.90 \\
\hline & Rectum & $35(38)$ & 11.4 & \\
\hline \multirow[t]{2}{*}{ Tumor stage } & II & 44 (47) & 13.4 & 0.009 \\
\hline & III & 49 (53) & 10.7 & \\
\hline \multirow[t]{3}{*}{ Differentiation grade } & Well & 13 (15) & 15.6 & \\
\hline & Moderate & $22(25)$ & 11.9 & 0.44 \\
\hline & Poor & $55(60)$ & 12.0 & \\
\hline \multirow[t]{2}{*}{ Mucinous } & No & $65(70)$ & 11.6 & 0.95 \\
\hline & Yes & $28(30)$ & 12.8 & \\
\hline \multirow{3}{*}{ HLA-A } & Absent & 12 (13) & 12.6 & \\
\hline & Heterogeneous & $53(59)$ & 12.8 & 0.15 \\
\hline & Normal & $25(28)$ & 9.0 & \\
\hline \multirow[t]{3}{*}{ HLA-B/C } & Absent & $8(9)$ & 6.7 & \\
\hline & Heterogeneous & $44(48)$ & 14.2 & 0.10 \\
\hline & Normal & $40(43)$ & 8.9 & \\
\hline \multirow{3}{*}{ TIL (HE-stained) } & Poor & 35 (38) & 11.8 & \\
\hline & Few & $43(46)$ & 11.7 & 0.42 \\
\hline & Marked & $15(16)$ & 14.9 & \\
\hline \multirow[t]{5}{*}{ CD4 IE } & Low & $70(75)$ & 12.6 & 0.49 \\
\hline & High & $23(25)$ & 10.6 & \\
\hline & $75 \mathrm{e} \mathrm{pct}^{\mathrm{b}}$ & 10 & & \\
\hline & Median $^{\mathrm{b}}$ & 3 & & \\
\hline & Range $^{\mathrm{b}}$ & $0-81$ & & \\
\hline \multirow[t]{3}{*}{ CD4 stroma } & No-poor & $42(45)$ & 11.4 & \\
\hline & Moderate & $28(30)$ & 12.7 & 0.29 \\
\hline & Marked & $23(25)$ & 13.7 & \\
\hline \multirow[t]{3}{*}{ CD4 margin } & No-poor & $36(40)$ & 10.8 & \\
\hline & Moderate & $35(38)$ & 13.5 & 0.11 \\
\hline & Marked & $20(22)$ & 11.9 & \\
\hline \multirow[t]{5}{*}{ CD8 IE } & Low & $70(75)$ & 12.0 & 0.12 \\
\hline & High & $23(25)$ & 15.0 & \\
\hline & $75 \mathrm{e} \mathrm{pct}{ }^{\mathrm{b}}$ & 65 & & \\
\hline & Median $^{\mathrm{b}}$ & 23 & & \\
\hline & Range $^{\mathrm{b}}$ & $0-603$ & & \\
\hline \multirow[t]{3}{*}{ CD8 stroma } & No-poor & $50(54)$ & 10.1 & \\
\hline & Moderate & 27 (29) & 13.9 & 0.29 \\
\hline & Marked & $16(17)$ & 11.8 & \\
\hline \multirow[t]{3}{*}{ CD8 margin } & Poor & $25(28)$ & 8.8 & \\
\hline & Moderate & $39(44)$ & 12.8 & 0.03 \\
\hline & Marked & $25(28)$ & 14.2 & \\
\hline \multirow[t]{5}{*}{ CD56 IE } & Low & $70(75)$ & 12.5 & 0.48 \\
\hline & High & $23(25)$ & 13.6 & \\
\hline & $75 \mathrm{e} \mathrm{pct}^{\mathrm{b}}$ & 5 & & \\
\hline & Median $^{\mathrm{b}}$ & 0 & & \\
\hline & Range $^{\mathrm{b}}$ & $0-170$ & & \\
\hline \multirow[t]{3}{*}{ CD56 stroma } & None & 49 (53) & 12.0 & \\
\hline & Poor & $29(31)$ & 12.2 & 0.50 \\
\hline & Moderate-marked & $15(16)$ & 10.6 & \\
\hline \multirow{3}{*}{ CD56 margin } & None & $62(69)$ & 12.2 & \\
\hline & Poor & $16(18)$ & 14.2 & 0.26 \\
\hline & Moderate-marked & 12 & 9.5 & \\
\hline
\end{tabular}

Laboratory Investigation (2004) 84, 493-501
Table 1 (continued)

\begin{tabular}{llccc}
\hline Parameter & & $\mathrm{n}(\%)$ & $\begin{array}{c}\text { Mean } \\
\text { DFS } \\
\text { (months) }\end{array}$ & P-value \\
& & \multicolumn{3}{c}{${ }^{\mathrm{a}}$} \\
CD57 IE & Low & $70(75)$ & 11.7 & 0.08 \\
& High & $23(25)$ & 16.1 & \\
& $75 \mathrm{e}$ pct & 2 & & \\
& Median $^{\mathrm{b}}$ & 0 & & \\
CD57 stroma & Range $^{\mathrm{b}}$ & $0-41$ & & \\
& No-poor $_{\text {CD57 margin }}$ & $62(67)$ & 12.3 & 0.30 \\
& Moderate-marked $30(33)$ & 12.2 & \\
& No-poor & $48(55)$ & 10.1 & \\
BM-like structure & Moderate & $29(33)$ & 16.1 & 0.06 \\
& Marked & $10(12)$ & 12.7 & \\
& Absent & $43(47)$ & 10.8 & \\
& Normal & $35(38)$ & 12.6 & 0.17 \\
& Thick & $14(15)$ & 13.0 & \\
& & & &
\end{tabular}

Patient and tumor characteristics are shown. The infiltration of CD4 ${ }^{+}$, $\mathrm{CD}^{+}, \mathrm{CD}^{2} 6^{+}$and $\mathrm{CD} 57^{+}$lymphocytes in the three compartments (ie intraepithelial (IE), tumor stroma and tumor margin) was assessed by double staining immunohistochemistry using the CD markers and laminin as previously described ${ }^{18}$ or an HE stain (tumor infiltrating leukocyte (TIL)). The intraepithelial lymphocytes were accurately counted and a correction was made for the amount of nontumor area in a particular slide. Infiltration in the tumor stroma and tumor margin was estimated semiquantitatively as described previously by Naito et al. ${ }^{7}$ The impact of each parameter on DFS was assessed using univariate analysis (Kaplan-Meier, log-rank test). DFS = Disease Free Survival; pct $=$ percentile; ${ }^{\mathrm{a}} \chi^{2}$ test.

${ }^{\mathrm{b}}$ Numbers are presented as intraepithelial infiltration $/ \mathrm{mm}^{2}$ tumor.

Three cases were excluded from the HLA analyses, because HLA-A expression could not be detected in tumor and normal tissue. HLA-A expression was normal in 25 cases (28\%), heterogenous in 53 cases (59\%) and absent in 12 cases (13\%). HLA-B/C expression was normal in 40 cases $(43 \%)$, heterogeneous in 44 cases $(47 \%)$ and absent in nine cases $(10 \%)$.

\section{Correlation of Leukocyte Infiltration in Different Tumor Compartments to Various Clinicopathological Parameters and Prognosis}

Infiltration of $\mathrm{CD}^{+}, \mathrm{CD}^{+}, \mathrm{CD} 6^{+}$and $\mathrm{CD} 7^{+}$cells in the various compartments was correlated with each other and clinical (age, sex) and tumor parameters (location, tumor stage, differentiation, mucinous features, HLA-A and HLA-B/C expression).

There was a positive correlation between leukocyte infiltration in the three compartments for CD4, CD8, CD56 (partly) and CD57 (all $P<0.05$, see Table 2 ), indicating that intraepithelial leukocyte infiltration is a reflection of infiltration in the tumor stroma and tumor margin. Intraepithelial CD56 infiltration did not correlate with CD56 infiltration in the tumor stroma $(P=0.38)$.

Intraepithelial CD8 infiltration inversely correlated with HLA-A $(P=0.04)$, HLA-B/C expression $(P=0.04$, see Table 3$)$ and tumor stage $(P=0.01$, Table 2). Intraepithelial CD57 infiltration inversely 
correlated with HLA-B/C expression $(P=0.04)$, but not with HLA-A expression $(P=0.74$, see Table 3$)$. Intraepithelial CD56 infiltration inversely correlated with tumor stage $(P=0.05$, Table 2$)$. There was no correlation between intraepithelial CD56 infiltration and HLA-A $(P=0.98)$ or BC expression $(P=0.43$, see Table 3).

Women and older patients had significantly more $\mathrm{CD}^{+}{ }^{+}$cell infiltration in the tumor stroma $(P=0.001$, data not shown) and older patients had more $\mathrm{CD} 57^{+}$cell infiltration in the advancing tumor margin $(P=0.04$, data not shown $) . \mathrm{CD}^{+}$cell infiltration in the tumor stroma was higher in lower stage tumors $(P=0.03$, data not shown). Intraepithelial $\mathrm{CD}^{+}{ }^{+}$cell infiltration was correlated to differentiation grade $(P=0.03$, data not shown).

Univariate (Table 1) and multivariate (Table 4) analyses were performed to assess the prognostic significance of leukocyte infiltration in the various compartments, patient factors and tumor features for DFS. A lower tumor stage $(P=0.004)$, marked CD8 ${ }^{+}$ $\left(P=0.04\right.$, see Figure 2) and $\operatorname{CD}^{+}(P=0.05$, see

Table 2 Correlations between leukocyte infiltration in the various tumor compartments and tumor stage

\begin{tabular}{|c|c|c|c|}
\hline \multirow[t]{2}{*}{ CD4 cell infiltration in: } & \multicolumn{3}{|c|}{ Intraepithelial CD4 cell infiltration } \\
\hline & Low & High & $P$-value ${ }^{\mathrm{a}}$ \\
\hline \multicolumn{4}{|l|}{ Tumor-stroma } \\
\hline None-poor & $37(88)$ & $5(12)$ & \multirow{3}{*}{0.002} \\
\hline Moderate & $20(71)$ & 8 (29) & \\
\hline Marked & $13(57)$ & $10(43)$ & \\
\hline \multicolumn{4}{|l|}{ Advancing margin } \\
\hline None-poor & $31(86)$ & $5(14)$ & \multirow{3}{*}{0.01} \\
\hline Moderate & $27(77)$ & $8(23)$ & \\
\hline Marked & $10(50)$ & $10(50)$ & \\
\hline \multirow[t]{2}{*}{ CD8 cell infiltration in: } & \multicolumn{3}{|c|}{ Intraepithelial CD8 cell infiltration } \\
\hline & Low & High & \\
\hline \multicolumn{4}{|l|}{ Tumor-stroma } \\
\hline None-poor & $45(90)$ & $5(10)$ & \multirow{3}{*}{$<0.001$} \\
\hline Moderate & $19(70)$ & $8(30)$ & \\
\hline Marked & $6(38)$ & $10(62)$ & \\
\hline \multicolumn{4}{|l|}{ Advancing margin } \\
\hline Poor & $24(96)$ & $1(4)$ & \multirow{3}{*}{0.001} \\
\hline Moderate & $30(77)$ & $9(23)$ & \\
\hline Marked & $13(52)$ & $12(48)$ & \\
\hline \multicolumn{4}{|l|}{ Tumor stage } \\
\hline II & $28(64)$ & $16(36)$ & \multirow[b]{2}{*}{0.01} \\
\hline III & $42(86)$ & $7(14)$ & \\
\hline \multirow[t]{2}{*}{ CD56 cell infiltration in: } & \multicolumn{3}{|c|}{ Intraepithelial CD56 cell infiltration } \\
\hline & Low & High & \\
\hline \multicolumn{4}{|l|}{ Tumor-stroma } \\
\hline None & $42(86)$ & 7 (14) & \multirow{3}{*}{0.03} \\
\hline Poor & $20(69)$ & $9(31)$ & \\
\hline Moderate-marked & $8(53)$ & $7(47)$ & \\
\hline
\end{tabular}

Table 2 (continued)

CD56 cell infiltration in: Intraepithelial CD56 cell infiltration

Low High P-value

Advancing margin

None-poor

Moderate

$12(75)$

$14(23)$

Marked

7 (58)

0.38

Tumor stage

II

$29(66) \quad 15(34)$

0.05

III

$41(84) \quad 8(16)$

CD57 cell infiltration in: Intraepithelial CD57 cell infiltration

\begin{tabular}{lrrr}
\cline { 2 - 3 } & Low & High & \\
\hline Tumor-stroma & & & \\
None-poor & $53(86)$ & $9(14)$ & 0.001 \\
Moderate-marked & $16(53)$ & $14(47)$ & \\
& & & \\
Advancing margin & $43(90)$ & $5(10)$ & \\
$\quad$ None-poor & $20(69)$ & $9(31)$ & $<0.001$ \\
Moderate & $3(30)$ & $7(70)$ & \\
$\quad$ Marked & & & \\
\end{tabular}

The number of cases with the specified amount of immune cell infiltration is shown with the percentages in parentheses. The intraepithelial infiltration of each lymphocyte was correlated to the infiltration in the tumor stroma and tumor margin. The $\chi^{2}$ test was used to evaluate significant differences between the groups. The intraepithelial infiltration of each CD marker correlated with the infiltration in the tumor stroma and the tumor magin, except for intraepithelial CD56 cell infiltration in the advancing margin $(P=0.38)$. Tumor stage inversely correlated with intraepithelial $\mathrm{CD}^{+}$and intraepithelial $\mathrm{CD}^{+} 6^{+}$cell infiltration.

${ }^{a} \chi^{2}$ test.

Figure 3) cell infiltration in the advancing tumor margin were correlated with a longer DFS in multivariate analysis. Evaluation of leukocyte infiltration on HE-stained tumor sections was not a prognostic factor for DFS ( $P=0.42$, Table 1$)$ and nor were any of the other investigated parameters (all $P>0.05$, Table 1).

\section{A BM-like Structure Prevents $\mathrm{CD8}^{+}$and $\mathrm{CD57}^{+}$Cell Infiltration into Tumor Cell Nests}

A BM-like structure could not be evaluated in one case and was found to be absent in 43 cases $(47 \%)$, normal in 35 cases $(38 \%)$ and thickened in 14 cases $(15 \%)$. The presence of a BM-like structure did not correlate with intraepithelial $\mathrm{CD}^{+}$and CD56 $^{+}$cell infiltration, but inversely correlated with intraepithelial $\mathrm{CD}^{+}$and $\mathrm{CD}^{+} 7^{+}$cell infiltration (see Table 5). A thick BM-like structure was observed in 14 cases and all these cases had low intraepithelial $\mathrm{CD}^{+}$and $\mathrm{CD}^{+} 7^{+}$leukocyte infiltration, while there were no cases with a high intraepithelial $\mathrm{CD}^{+}$and $\mathrm{CD}^{+} 7^{+}$cell infiltration that had a thick BM-like structure $(P=0.003$ and 0.04 , respectively). 
Table 3 HLA-A and HLA-B/C expression on tumor cells and intraepithelial tumor infiltrate

\begin{tabular}{|c|c|c|c|c|c|c|c|c|}
\hline & \multicolumn{3}{|c|}{$H L A-A$} & \multirow[t]{2}{*}{$P$-value } & \multicolumn{3}{|c|}{ HLA-B/C } & \multirow[t]{2}{*}{$P$-value } \\
\hline & None & Heterogenous & Normal & & None & Heterogeneous & Normal & \\
\hline \multicolumn{9}{|l|}{$C D 4$} \\
\hline Low & $7(58)$ & $43(81)$ & 19 (76) & 0.24 & $6(75)$ & $32(73)$ & $32(80)$ & 0.74 \\
\hline High & $5(42)$ & $10(19)$ & $6(23)$ & & $2(25)$ & $12(27)$ & $8(20)$ & \\
\hline \multicolumn{9}{|l|}{ CD8 } \\
\hline Low & $6(50)$ & $41(77)$ & 22 (88) & 0.04 & $4(50)$ & $31(71)$ & 35 (88) & 0.04 \\
\hline High & $6(50)$ & $12(23)$ & $3(12)$ & & $4(50)$ & $12(29)$ & $5(12)$ & \\
\hline \multicolumn{9}{|l|}{$C D 56$} \\
\hline Low & $9(75)$ & $41(77)$ & $19(76)$ & 0.98 & $7(88)$ & $31(71)$ & $32(80)$ & 0.43 \\
\hline High & $3(25)$ & $12(23)$ & $6(24)$ & & $1(12)$ & $13(29)$ & $8(20)$ & \\
\hline \multicolumn{9}{|l|}{ CD57 } \\
\hline Low & $8(67)$ & $41(77)$ & 19 (76) & 0.73 & $4(50)$ & $31(71)$ & $35(88)$ & 0.04 \\
\hline High & $4(33)$ & $12(23)$ & $6(24)$ & & $4(50)$ & $13(29)$ & $5(12)$ & \\
\hline
\end{tabular}

${ }^{\mathrm{a}} \chi^{2}$ test.

HLA-A and HLA-B/C expressions on tumor cells were correlated to intraepithelial CD4 ${ }^{+}$, CD8 ${ }^{+}$, CD56 ${ }^{+}$and CD57 ${ }^{+}$cell infiltration. The number of cases with the specified amount of immune cell infiltration is shown with the percentages in parentheses. Intraepithelial CD8 ${ }^{+}$cell infiltration inversely correlated with HLA-A and HLA-B/C expression. Intraepithelial CD57 ${ }^{+}$cell infiltration inversely correlated with HLA-B/C expression, but not with HLA-A expression. Intraepithelial CD4 ${ }^{+}$and CD56 ${ }^{+}$cell infiltration did not correlate with HLA-A or HLA-B/C expression.

Table 4 Multivariate analysis

\begin{tabular}{lccl}
\hline Parameter & Hazard ratio & $95 \%$ CI & $P$-value \\
\hline Tumor stage & 3.77 & $1.54-9.21$ & 0.004 \\
CD8 margin & 0.56 & $0.32-0.99$ & 0.04 \\
CD57 margin & 0.42 & $0.17-1.01$ & 0.05 \\
\hline
\end{tabular}

All clinical and tumor parameters were entered in a multivariate analysis. Tumor stage, infiltration of CD8 and CD57 cells at the advancing tumor margin were independent prognostic factors for DFS.

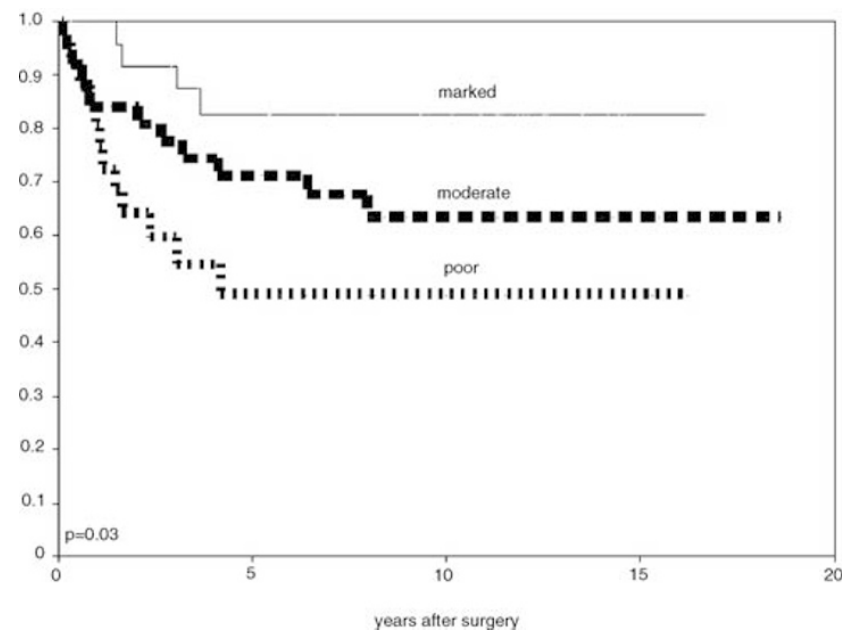

Figure 2 DFS was compared between patients with poor, moderate and marked $\mathrm{CD}^{+}$stromal cell infiltration at the advancing tumor margin (log-rank test). There was a significant positive correlation between the number of $\mathrm{CD}^{+}$and $\mathrm{CD} 57^{+}$ lymphocytes and a longer DFS. $P$-values are shown for univariate and not for multivariate analysis.



Figure 3 Same as Figure 2, only DFS was compared between patients with poor, moderate and marked $\mathrm{CD} 57^{+}$stromall cell infiltration here.

\section{Importance of MSI for Leukocyte Infiltration}

MSI was evaluated immunohistochemically by staining for the expression for one of the most commonly altered mismatch repair proteins in sporadic colorectal cancer, MLH1. MLH1 expression was absent in six cases (7\%, indicating $\left.\mathrm{MSI}^{+}\right)$, present in 84 cases $\left(93 \%\right.$, indicating $\left.\mathrm{MSI}^{-}\right)$and could not be assessed in three cases. There were no significant differences in $\mathrm{CD} 4^{+}, \mathrm{CD}^{+}, \mathrm{CD}^{+} 6^{+}$and $\mathrm{CD} 7^{+}$cell infiltration in the tumor stroma and tumor margin compartment between $\mathrm{MSI}^{-}$ and $\mathrm{MSI}^{+}$tumors (data not shown). However, intraepithelial $\mathrm{CD}^{+}$and $\mathrm{CD}^{+} 7^{+}$cell infiltration 
Table 5 Expression of a BM-like structure inversely correlates with intraepithelial CD8 and CD57 infiltration

\begin{tabular}{lrrrr}
\hline \multirow{2}{*}{ Intraepithelial infiltration } & \multicolumn{5}{c}{ BM-Like structure } \\
\cline { 2 - 5 } & Absent & Normal & Thick & P-value \\
& & & & \\
CD4 & $35(81)$ & $23(66)$ & $11(79)$ & \\
Low & $8(19)$ & $12(34)$ & $3(21)$ & 0.27 \\
High & & & & \\
CD8 & $35(81)$ & $20(57)$ & $14(100)$ & \\
Low & $8(19)$ & $15(43)$ & - & 0.003 \\
High & & & & \\
CD56 & $32(74)$ & $25(71)$ & $12(86)$ & \\
Low & $11(26)$ & $10(29)$ & $2(14)$ & 0.58 \\
High & & & & \\
CD57 & $32(74)$ & $23(66)$ & $14(100)$ & \\
Low & $11(26)$ & $12(34)$ & - & 0.04 \\
High & & &
\end{tabular}

The presence of a BM-like structure surrounding tumor cells was correlated to the amount of intraepithelial lymphocyte infiltration. The number of cases with the specified amount of immune cell infiltration is shown with the percentages in parentheses. The number of intraepithelial $\mathrm{CD}^{+}$and $\mathrm{CD} 57^{+}$cells decreased significantly when BM-like structures were thicker.

$\mathrm{a}=\chi^{2}$-test.

Percentages are displayed in parentheses.

was significantly higher in $\mathrm{MSI}^{+}$tumors (see Table 6). The median intraepithelial CD8 ${ }^{+}$cell infiltration was 189 cells $/ \mathrm{mm}^{2}$ tumor in $\mathrm{MSI}^{+}$tumors, but only 21 cells $/ \mathrm{mm}^{2}$ tumor in MLH1-positive tumors $(P=0.03)$. The median intraepithelial $\mathrm{CD} 7^{+}$cell infiltration was 12 and 0 cells $/ \mathrm{mm}^{2}$, respectively $(P=0.006)$. A correlation between MSI and DFS was not performed, due to the limited number of MSIhigh cases.

\section{Discussion}

In the present study, we showed that $\mathrm{CD}^{+}$and $\mathrm{CD} 7^{+}$stromal cells at the advancing tumor margin are important prognostic factors in colorectal cancer. Moreover, direct contact with tumor cells plays a crucial role, especially in $\mathrm{MSI}^{+}$tumors. Although our observation that $\mathrm{CD}^{+}$and $\mathrm{CD}^{+} 7^{+}$cell infiltration in the advancing tumor margin were independent prognostic factors may seem in contrast with this notion of direct contact, the discrepancy can be explained by the fact that tumor cell - immune cell interactions are underestimated, especially at the advancing tumor margin due to the production of ECM proteins by these tumor cells. ${ }^{19}$ In addition, it has been demonstrated that BM-like structures surrounding tumor nodules are more frequently discontinuous at the advancing tumor margin, which enhances direct contact between tumor cells and leukocytes. ${ }^{20}$ Interestingly, Suzuki et $a l^{21}$ recently showed that it is exactly at this advancing margin where mature dendritic cells (DCs) cluster
Table 6 Median leukocyte infiltration on the basis of MLH-1 expression

\begin{tabular}{lccc}
\hline & \multicolumn{2}{c}{ MLH1 expression } & \multirow{2}{*}{ P-value $^{\mathrm{a}}$} \\
\cline { 2 - 3 } & Negative $(\mathrm{n}=6)$ & Positive $(\mathrm{n}=84)$ & \\
\hline CD4 & $4(1-52)$ & $3(0-81)$ & 0.65 \\
CD8 & $189(17-329)$ & $21(0-603)$ & 0.03 \\
CD56 & $1(0-12)$ & $1(0-170)$ & 0.85 \\
CD57 & $12(0-23)$ & $0(0-41)$ & 0.006 \\
\hline
\end{tabular}

The median lymphocyte infiltration per $\mathrm{mm}^{2}$ tumor and the range (parentheses) are displayed on the basis of MLH1 expression. Tumors without MLH1 expression represent $\mathrm{MSI}^{+}$tumors. $\mathrm{MSI}^{+}$tumors had significantly higher intraepithelial $\mathrm{CD}^{+}$and $\mathrm{CD} 57^{+}$cell infiltration.

${ }^{\mathrm{a}}$ Kruskal-Wallis test.

with $\mathrm{CD}^{+}$and $\mathrm{CD}^{+}$cells. Morse et $a l^{22}$ described similar findings in colorectal hepatic metastases after Flt 3 ligand administration, which mobilizes DCs. Dendritic cells play an important role in the generation and regulation of the innate (NK cells) and adaptive immune system (CTL). ${ }^{23}$ From these data, a scenario can be envisioned in which the intraepithelial leukocyte infiltration is a reflection of the immune reaction that is elicited at the advancing tumor margin. In our study, there was a positive correlation between the number of $\mathrm{CD}^{+}$and $\mathrm{CD}^{2} 7^{+}$cells in the advancing margin and those in direct contact with tumor cells. Tanaka et al presented concordant findings in a mouse model. ${ }^{24}$ They showed that activation of NK cells induced tumor cell death, which subsequently activated DCs and induced CTL responses. Direct contact between these cells was an essential requirement. The primary tumor provides us with important information regarding its immunogenicity. Although we did not evaluate lymphocyte infiltration in the metastases and corresponding primary tumors, and to our knowledge this has also not been investigated by others, we suggest that the lymphocytic infiltration in a primary tumor is a good reflection of the infiltration in its metastases. In a previous study of 82 primary tumors and 143 liver metastases, we found that p53 and HLA class I expression was similar in both lesions (Menon et al, unpublished results).

We also found that the presence of a BM-like structure was inversely correlated to $\mathrm{CD}^{+}$and $\mathrm{CD} 7^{+}$cell infiltration intraepithelially. This is in accordance with previous findings in animal models, ${ }^{8}$ in human subjects with colorectal cancer ${ }^{10}$ and with electron microscopy data that indicate that the permeability of BMs is altered in pathological conditions. ${ }^{25}$ Alternatively, the production of immune-inhibitory cytokines, such as FAS-L, IL-10 or TGF- $\beta$ may also explain the observed discrepancies in leukocyte infiltration. ${ }^{26-29}$ Regarding the question as to which arm of the immune systems plays the most significant role in the antitumor 
effect, it is generally believed that the activation of tumor-specific, cytotoxic $\mathrm{T}$ cells plays a more prominent role than the leukocytes involved in innate immunity (eg NK cells). In the present study, we provided evidence that NK cells or NK-like T cells also play an important role. Although we did not perform a CD3-laminin double-staining to distinguish between CTL and NK cells, we found that $\mathrm{CD}^{+}$and $\mathrm{CD}^{+} 7^{+}$cell infiltration provided independent prognostic information for prognosis and both markers inversely correlated with HLA-I expression on tumor cells. We found that $\mathrm{CD}^{2} 7^{+}$cell infiltration was inversely correlated to HLA-B/C expression, but not HLA-A expression. This can be explained by taking into account that NK cells are activated by the loss of certain HLA loci, for example, HLA-C. ${ }^{15}$ This latter finding has important implications for immunotherapy, as most studies aim at inducing CTL. However, we would advocate the investigation of immunotherapies that, in addition to tumor-specific $\mathrm{T}$ cells, will also activate NK cells or NK-like T cells, as stressed by others. ${ }^{30-32}$ For instance, the activation of NK cells and DCs with anti-CD40, ${ }^{33}$ recombinant IL-18, ${ }^{24}$ Flt3 $^{22}$ or protein-pulsed $\mathrm{DCs}^{34}$ are already under investigation.

The finding that tumors with MSI are especially associated with the infiltration of $\mathrm{CD}^{+}$and $\mathrm{CD} 57^{+}$ cells in the tumor-epithelium compartment would offer a plausible explanation for the good prognosis that is seen in these patients. $\mathrm{MSI}^{+}$tumors harbor numerous mutations that lead to the production of altered, potentially immunogenic epitopes that can induce CTL. ${ }^{35}$ However, the induction of CTL responses takes time, leaving time for tumor cells to escape the immune system. Therefore, NK cells may play an important role, as they do not require prior sensitization and therefore are able to eliminate metastasizing HLA-nonexpressing cells instantaneously. In addition, NK cells are abundantly present in the systemic circulation and in the liver, the first organ of tumor cell dissemination in most patients with colorectal cancer. ${ }^{36}$. Especially, patients with $\mathrm{MSI}^{+}$tumors may benefit from immunotherapy and patients with HNPCC may be able to receive preventive vaccinations, for instance, as described above that stimulate NK and T cells. Future studies should further explore the role of the various immune effector cells on the basis of reacting to frameshift proteins, as it may have important consequences for the selection of patients for adjuvant immunotherapy.

In conclusion, we report that in addition to tumor stage, infiltration of $\mathrm{CD}^{+}$and $\mathrm{CD}^{+} 7^{+}$cells in the tumor margin are independent prognostic factors in colorectal cancer patients. The infiltration of these immune effector cells into tumor cell nests is inversely correlated with the presence of a BM-like structure around the tumor cell nests and the presence of certain HLA-I loci. Furthermore, we propose further exploration of NK cell-mediated immunotherapy and a role for MSI in the selection of patients for immunotherapy.

\section{References}

1 Svennevig JL, Lunde OC, Holter J, et al. Lymphoid infiltration and prognosis in colorectal carcinoma. Br J Cancer 1984;49:375-377.

2 Di Giorgio A, Botti C, Tocchi A, et al. The influence of tumor lymphocytic infiltration on long term survival of surgically treated colorectal cancer patients. Int Surg 1992;77:256-260.

3 Ropponen KM, Eskelinen MJ, Lipponen PK, et al. Prognostic value of tumour-infiltrating lymphocytes (TILs) in colorectal cancer. J Pathol 1997;182:318-324.

4 Jass JR, Love SB, Northover JM. A new prognostic classification of rectal cancer. Lancet 1987;1:13031306.

5 Jass JR, Ajioka Y, Allen JP, et al. Assessment of invasive growth pattern and lymphocytic infiltration in colorectal cancer. Histopathology 1996;28:543-548.

6 Michael-Robinson JM, Biemer-Huttmann A, Purdie $\mathrm{DM}$, et al. Tumour infiltrating lymphocytes and apoptosis are independent features in colorectal cancer stratified according to microsatellite instability status. Gut 2001;48:360-366.

7 Naito Y, Saito K, Shiiba K, et al. CD8 ${ }^{+}$T cells infiltrated within cancer cell nests as a prognostic factor in human colorectal cancer. Cancer Res 1998;58:34913494.

8 Hagenaars M, Ensink NG, Basse PH, et al. The microscopic anatomy of experimental rat CC531 colon tumour metastases: consequences for immunotherapy? Clin Exp Metastasis 2000;18:189-196.

9 Offerhaus GJ, Giardiello FM, Bruijn JA, et al. The value of immunohistochemistry for collagen IV expression in colorectal carcinomas. Cancer 1991;67:99-105.

10 Menon AG, Fleuren GJ, Alphenaar EA, et al. A basal membrane-like structure surrounding tumour nodules may prevent intraepithelial leucocyte infiltration in colorectal cancer. Cancer Immunol Immunother 2003;52:121-126.

11 Boland CR, Thibodeau SN, Hamilton SR, et al. A National Cancer Institute Workshop on Microsatellite Instability for cancer detection and familial predisposition: development of international criteria for the determination of microsatellite instability in colorectal cancer. Cancer Res 1998;58:5248-5257.

12 Dolcetti R, Viel A, Doglioni C, et al. High prevalence of activated intraepithelial cytotoxic T lymphocytes and increased neoplastic cell apoptosis in colorectal carcinomas with microsatellite instability. Am J Pathol 1999;154:1805-1813.

13 Guidoboni M, Gafa R, Viel A, et al. Microsatellite instability and high content of activated cytotoxic lymphocytes identify colon cancer patients with a favorable prognosis. Am J Pathol 2001;159:297-304.

14 Jonges LE, Albertsson P, van Vlierberghe RL, et al. The phenotypic heterogeneity of human natural killer cells: presence of at least 48 different subsets in the peripheral blood. Scand J Immunol 2001;53:103-110.

15 Rolstad B, Seaman WE. Natural killer cells and recognition of MHC class I molecules: new perspectives and challenges in immunology. Scand J Immunol 1998;47:412-425. 
16 Browning M, Petronzelli F, Bicknell D, et al. Mechanisms of loss of HLA class I expression on colorectal tumor cells. Tissue Antigens 1996;47:364-371.

17 Menon AG, Morreau H, Tollenaar RA, et al. Downregulation of HLA-A expression correlates with a better prognosis in colorectal cancer patients. Lab Invest 2002;82:1725-1733.

18 Jonges LE, Nagelkerke JF, Ensink NG, et al. Caspase-3 activity as a prognostic factor in colorectal carcinoma. Lab Invest 2001;81:681-688.

19 Kirchner T, Brabletz T. Patterning and nuclear betacatenin expression in the colonic adenoma-carcinoma sequence. Analogies with embryonic gastrulation. Am J Pathol 2000;157:1113-1121.

20 Hewitt RE, Powe DG, Griffin NR, et al. Relationships between epithelial basement membrane staining patterns in primary colorectal carcinomas and the extent of tumour spread. Int J Cancer 1991;48: 855-860.

21 Suzuki A, Masuda A, Nagata H, et al. Mature dendritic cells make clusters with T cells in the invasive margin of colorectal carcinoma. J Pathol 2002;196:37-43.

22 Morse MA, Nair S, Fernandez-Casal M, et al. Preoperative mobilization of circulating dendritic cells by Flt3 ligand administration to patients with metastatic colon cancer. J Clin Oncol 2000;18:3883-3893.

23 Steinman RM. The dendritic cell system and its role in immunogenicity. Annu Rev Immunol 1991;9:271-296.

24 Tanaka F, Hashimoto W, Okamura H, et al. Rapid generation of potent and tumor-specific cytotoxic $\mathrm{T}$ lymphocytes by interleukin 18 using dendritic cells and natural killer cells. Cancer Res 2000;60:48384844.

25 McAlindon ME, Gray T, Galvin A, et al. Differential lamina propria cell migration via basement membrane pores of inflammatory bowel disease mucosa. Gastroenterology 1998;115:841-848.

26 O’Connell J, Bennett MW, O’Sullivan GC, et al. Fas ligand expression in primary colon adenocarcinomas: evidence that the Fas counterattack is a prevalent mechanism of immune evasion in human colon cancer. J Pathol 1998;186:240-246.

27 Tsushima H, Kawata S, Tamura S, et al. High levels of transforming growth factor beta 1 in patients with colorectal cancer: association with disease progression. Gastroenterology 1996;110:375-382.

28 Robson H, Anderson E, James RD, et al. Transforming growth factor beta 1 expression in human colorectal tumours: an independent prognostic marker in a subgroup of poor prognosis patients. Br J Cancer 1996;74:753-758.

29 Wojtowicz-Praga S. Reversal of tumor-induced immunosuppression: a new approach to cancer therapy. J Immunother 1997;20:165-177.

30 Coca S, Perez PJ, Martinez D, et al. The prognostic significance of intratumoral natural killer cells in patients with colorectal carcinoma. Cancer 1997;79: 2320-2328.

31 Tartter PI, Steinberg B, Barron DM, et al. The prognostic significance of natural killer cytotoxicity in patients with colorectal cancer. Arch Surg 1987;122:1264-1268.

32 Whiteside TL, Herberman RB. The role of natural killer cells in immune surveillance of cancer. Curr Opin Immunol 1995;7:704-710.

33 Turner JG, Rakhmilevich AL, Burdelya L, et al. AntiCD40 antibody induces antitumor and antimetastatic effects: the role of NK cells. J Immunol 2001;166: 89-94.

34 Marten A, Schottker B, Ziske C, et al. Increase of the immunostimulatory effect of dendritic cells by pulsing with CA 19-9 protein. J Immunother 2000;23:464-472.

35 Linnebacher M, Gebert J, Rudy W, et al. Frameshift peptide-derived T-cell epitopes: a source of novel tumor- specific antigens. Int J Cancer 2001;93:6-11.

36 Rushfeldt C, Sveinbjornsson B, Seljelid R, Smedsrod B. Early events of hepatic metastasis formation in mice: role of Kupffer and NK-cells in natural and interferon-gamma-stimulated defense. J Surg Res 1999;82:209-215. 